\title{
REVIRAVOLTA NEGRA: UMA BREVE ANÁLISE DO DISCURSO LITERÁRIO “O FILHO DE LUÍSA”, DE JOEL RUFINO DOS SANTOS
}

Jonatas Eliakim

\section{Introdução}

Durante a história brasileira, o povo negro passou por um longo silêncio imposto. As vidas de homens e mulheres escravizados, de sua descendência e suas raízes foram apagadas. Nesse processo, até mesmo os movimentos culturais que nasciam no seio da comunidade de negros foram criminalizados e rechaçados pelos brancos. Mas, ao mesmo tempo, a história dessa sociedade é um epítome de resistência e de luta. Hoje, parte dessa luta se dá pela escrita/narração da própria história.

$\mathrm{O}$ ato de escrever ou narrar é tido pela sociedade negra como uma obrigação moral. A negritude, assim, incorpora a crença de 
que a história pode ser "interrompida, apropriada e transformada através da prática artística e literária”, como afirma hooks (1990, p. 152). Desse modo, é por meio da narração, ou melhor, da autonarração que é possível apropriar-se da própria vida, transformar a própria realidade.

Para bell hooks $(1989,1990)$, a resistência da sociedade negra a partir da criação literária é uma busca pela posição de sujeito, porque apenas os sujeitos "têm o direito de definir suas próprias realidades, estabelecer suas próprias identidades, de nomear suas histórias" (hooks, 1989, p. 42). Do contrário, a realidade do negro é definida por outros, suas identidades são criadas e sua "história designada somente de maneiras que definem a relação com aqueles que são sujeitos” (hooks, 1989, p. 42).

É por esse viés que este capítulo busca, ao tomar o conto "O filho de Luísa”, de Joel Rufino dos Santos, como discurso, analisar como o discurso literário, porque paratópico, veicula identidades construídas na e pela enunciação, de modo a ser um poderoso discurso na nossa sociedade para o ato de resistência, de decolonização, que buscam os sujeitos negros. Para isso, tem-se como fundamentação teórica a Análise de Discurso, especialmente a perspectiva enunciativo-discursiva de Dominique Maingueneau (2001, 2008, 2016, 2018).

Aqui, verificamos que a importância de se analisar o discurso literário de Joel Rufino Santos, principalmente a partir dos textos dedicados às crianças e aos jovens, dá-se pela compreensão de que seu trabalho configura um relevante meio de estudos sobre as identidades, com ênfase nas identidades negras, além de permitir que se amplie a consciência da luta constante que é a vida do povo negro. 
Para atender o proposto, dividimos este trabalho em três partes. Num primeiro momento, apresentamos, as condições de produção do discurso literário "O filho de Luísa”, em seguida abordamos a noção de discurso e situamos as bases teóricas para a análise, e, por fim, apresentamos o corpus e uma breve análise.

\section{O filho de Luísa}

O texto de "O filho de Luísa" foi publicado pela Revista Nova Escola em 1993, em uma série de contos que, posteriormente, foram compilados em formato de livro sob o título "Gosto de África: histórias de lá e daqui”. O livro é composto por sete contos que trazem narrativas adaptadas de lendas tradicionais dos povos africanos, e personagens da história do Brasil, sempre com enfoque na história da população negra.

O autor, Joel Rufino dos Santos, é um conhecido historiador e professor universitário, e suas pesquisas investigam as raízes históricas brasileiras. Como historiador, boa parte de seu trabalho é dedicado a recuperar lendas, mitos e tradições da cultura negra. Além disso, em sua produção literária, o escritor traz narrativas vinculadas à oralidade aliadas à temática dos povos excluídos e das vozes muitas vezes silenciadas nos discursos oficiais.

Em "O filho de Luísa”, em uma escrita metalinguística, o narrador apresenta uma personagem negra livre e mulçumana, que vivia na Bahia de Todos os Santos e pertencia à sociedade secreta de negros malês. A vida de Luísa, mulher guerreira, é feita também de paixões, em especial pelo branco Oliveira que consegue sua soltura em 1835, quando estoura a Revolução dos Malês. 
Quando descobre a gravidez, o casal promete que vai abandonar o passado - ele o mundo da jogatina, ela a revolução. Nascido o menino, deram-lhe o nome de Luís "Era negro fosco como Luísa e tinha a testa alta e o nariz como Oliveira” (Santos, 2005, p. 13). No entanto, as promessas foram em vão, pois Luísa se envolve em outra revolta - a Sabinada - e é novamente presa, e Oliveira, por seu turno, envolvido pelo vício, perde grande quantidade de dinheiro no jogo e entrega o menino como mercadoria para pagar sua dívida.

Da Bahia para o Rio de Janeiro, do Rio de Janeiro para São Paulo, escravizado, o menino aprendeu com os sinhozinhos a ler e escrever. Estudando se tornou rábula, e conseguiu lutar por sua liberdade e "Começou provando no tribunal que tinha direito à liberdade, pois era filho de uma mulher livre. Em seguida, iniciou - junto com outros estudantes e jornalistas - a Campanha Abolicionista”. (Santos, 2005, p. 14).

Joel Rufino dos Santos traz à cena dois personagens históricos, Luísa Mahin - a mãe - e Luís Gama - o filho. A primeira quase anônima - o que se tem de registro foi construído pelo próprio Luís Gama - e o segundo, embora pouco lembrado nos relatos oficiais, teve destaque como jornalista, poeta e advogado abolicionista.

Sobre o livro, a sinopse informa

Contadas por quem sabe cativar o leitor, a narrativa flui com simplicidade, como se saísse da boca dos velhos contadores de história. Uma boa história pode começar de qualquer maneira. Esta começa com uma quitandeira da Bahia... Essa história aconteceu há dez mil anos... 
no interior do Maranhão tem uma vila... Esta é uma história de vontade. Numa fazenda de gado à beira do rio São Francisco...

Através dessas histórias o leitor poderá descobrir outros tempos, outros lugares e valores. E, assim, ter outro olhar para o presente e para o futuro. (SANTOS, 2005)

Esse paratexto explicita os objetivos da compilação em livro, permitir ao leitor conquistar um novo olhar para a História. E isso se dá por meio do discurso literário.

\section{Discurso literário}

O discurso literário tem seu espaço na sociedade estabelecido de maneira contraditória e controversa. Se, por um lado, a literatura é exaltada como um veículo de descompressão dos pensamentos, de abundância de mundos e possibilidades, de pluralidade de seres, de aceitação do diferente; por outro, ela também é o espaço de conservação da memória de uma sociedade, da tradição, de recuperação de um passado imemorial etc. E o autor, então, se encontra exatamente no centro desse embate, sua criação não está assegurada por uma instituição que oferece bases sólidas para a produção, de modo que não podemos afirmar que o discurso literário valida a si mesmo.

Assim, quando voltamos o nosso olhar para as produções literárias brasileiras do século XXI, podemos perceber que, mesmo que esse seja um momento literário singular, pelo menos em termos quantitativos quando pensamos no volume de textos, essa profícua produção aponta mais para uma ampliação de espaços 
dados à literatura, à medida que possibilitam novos nichos de circulação literária, do que se volta como um subsídio para a própria criação.

Do mesmo modo, verificamos que, no campo literário brasileiro contemporâneo, há uma busca por profissionalização de um ofício de escritor, com a organização de maneira mais consistente de participação em festivais e feiras literárias e um mercado editorial forte, em que circula um montante de mais de $\mathrm{R} \$ 5$ bilhões por $\mathrm{ano}^{8}$.

Entretanto, a posição de autor não pode ser encarada apenas como um ofício técnico quando analisamos o discurso literário. Ora, o trabalho de criação de uma obra literária vai além de uma lapidação das palavras ou estilização de frases, pois o autor não apenas enuncia um discurso, como também constrói as condições de produção do próprio discurso. Assim, o discurso literário está intrinsecamente associado ao espaço social ocupado pelo autor, caracterizado pela posição paradoxal entre um lugar e um não-lugar, considerando o isolamento social do autor que não possui um lugar definido quando inserido no processo de criação (MAINGUENEAU, 2018).

Ora, a Análise do Discurso questiona a visão de Literatura que vigorou nos estudos literários durante os séculos XIX e XX (MAINGUENEAU, 2018), uma visão que estava focada na figura do autor, seja ao tentar justificar a obra com questões da biografia, seja a partir do estudo do contexto do autor. Diferente disso, Maingueneau (2018) propõe que o texto literário não seja encarado como restrito exclusivamente ao ato de uma instância criadora, mas, como todo discurso, é necessário considerar em uma análise as condições do dizer que atravessam o dito, responsáveis por re-

8 Segundo a pesquisa FIPE de 2020. 
meter às suas próprias condições de enunciação. Nessas condições, estão implicados o gênero, o posicionamento, a relação com o destinatário por meio do texto, os suportes, como os enunciados circulam, entre outras categorias.

Nas palavras do autor,

quando se olha apara a literatura como discurso (...) é-se levado a contestar uma visão tradicional dos estudos literários em duas vertentes: uma que se volta para o texto, encarado em si mesmo, e outra para o contexto (a vida do autor, um ou outro aspecto da época na qual ele viveu). (MAINGUENEAU, 2018, p.30)

Maingueneau (2005) entende o texto literário como um evento discursivo, no qual é possível analisar elementos da enunciação que não eram contemplados na perspectiva romântica dos estudos da Literatura. Nesse sentido, o discurso literário permite um olhar interdisciplinar a partir da Linguística e da Literatura, sobre o fenômeno linguístico. Sendo assim, essa noção de discurso literário não está reservada ao regime de literatura moderna, ou seja, ela pode ser aplicada a qualquer fato literário que que permite o agrupamento de fenômenos que pertencem a épocas e sociedades muito diversas sem considerar o autor.

Tomar a literatura enquanto discurso, então, traz uma série de pressupostos fundamentais para a construção de uma análise, ou seja, o discurso literário:

- $\quad$ está submetido às regras de organização que governam os gêneros de discurso em vigor em um determinado grupo social e às regras transversais do gênero. É uma forma 
de ação sobre o outro, nesse sentido, não se trata apenas de uma representação de mundo, afinal toda enunciação constitui um ato que visa modificar uma situação;

- é interativo, ou seja, constitui uma interatividade que envolve dois ou mais parceiros, como orienta Maingueneau (2015, p. 23): "qualquer enunciação supõe a presença de outra instância de enunciação, em relação à qual alguém constrói seu próprio discurso";

- é contextualizado, assim, não apenas intervém em um contexto, como se esse contexto não passasse de uma moldura ou cenário: fora dele, não se pode atribuir sentido aos enunciados;

- é regido por normas, como qualquer comportamento social. O discurso literário, como atividade verbal, obedece a normas, tratados e leis que regem as trocas verbais. Dessa maneira, verifica-se que os efeitos de sentido são construídos socialmente, eles não são estáveis ou imanentes a um enunciado ou a um grupo de enunciados, mas são continuamente construídos e reconstruídos no interior das práticas sociais;

- deve ser assumido no bojo do interdiscurso.

A interdiscursividade, aqui, se liga ao posicionamento do autor, que define uma identidade enunciativa, um lugar de produção discursiva específico (CHARAUDEAU \& MAINGUENEAU, 2004). O termo designa, ao mesmo tempo, as operações pelas quais a identidade enunciativa se instaura e se conserva em um campo discursivo e a própria identidade. Desse modo, o posicionamento do autor se manifesta na escolha dos gêneros do discurso e nos discursos com os quais mantém uma relação de interdiscursividade. 
Para cada posicionamento, ao lado do investimento de um ou outro gênero do interdiscurso, há o investimento de uma interlíngua pela qual o discurso se inscreve no espaço das práticas verbais. É pode meio das condições sociodiscursivas materializadas em marcas linguísticas que distinguem espaços enunciativos que se inscrevem imagens autorais ou identidades.

Esses espaços são as "instâncias de inscrição da subjetividade" (MAINGUENEAU, 2018). Desse modo, uma análise da autoralidade abrange as condições de produção e recepção de determinado discurso. A identidade enunciativa está ligada a essas condições, uma vez que a imagem de autor é inscrita na enunciação e gerida por editores e comunidade discursiva. Além disso, as obras podem ser abordadas, paralelamente, quanto sua associação a gêneros historicamente instituídos e à autoria, sem que haja contradição na análise. O conceito de "instâncias da enunciação", portanto, propõe noções fundamentais para a abordagem da construção interdiscursiva de uma "identidade criadora".

Na perspectiva da $\mathrm{AD}$, o discurso literário não é encarado de forma isolada apesar de sua especificidade, mas participa de um plano determinado de produção verbal que é o dos discursos constituintes. O adjetivo "constituintes", atribuído a esses discursos, segundo Maingueneau (2000), explora três valores semânticos associados ao verbo constituir e a seu derivado, o substantivo constituição.

Ao tomar o termo constituição como ação de se estabelecer legalmente, possibilita caracterizar o discurso como instaurando as modalidades de sua própria emergência no interior do interdiscurso, ideia que se inscreve no prolongamento de certas correntes pragmáticas que ligam a enunciação estreitamente à sua legitimação. 
A constituição tomada como forma de organização, agenciamento de constituintes possibilita evidenciar a coesão/coerência das totalidades textuais. Já a constituição como conjunto de disposições legais que determinam os direitos e deveres de cada indivíduo na coletividade, possibilita destacar que o discurso constituinte está destinado a servir de norma e de garantia aos comportamentos de uma coletividade, delimitando um lugar comum das palavras que aí podem circular.

Os discursos constituintes, plano de ação verbal dentro do qual o discurso literário se enquadra, propõem-se como discursos de Origem, os quais são validados por uma cena de enunciação que autoriza a si mesma. São discursos que fundam outros discursos e constituem uma categoria discursiva propriamente dita. Nessa perspectiva, o discurso literário está associado ao trabalho de fundação no e pelo discurso e se vincula um grupo de locutores consagrados e responsáveis pela elaboração de uma memória.

Por ser constituinte, o discurso literário dá sentido aos atos da coletividade e funciona como garante de uma multiplicidade de gêneros do discurso.

São a um só tempo autoconstituintes e heteroconstituinte, duas faces que se pressupõem mutuamente: só um discurso que se constitui ao tematizar sua própria constituição pode desempenhar o papel constituinte com relação a outros discursos. (MAINGUENEAU, 2018, p. 61)

Trata-se de um discurso paratópico, ou seja, quem enuncia, nesse tipo de discurso, não ocupa um lugar, nem fora nem dentro da sociedade, mas um lugar problemático (Mainguene- 
au, 2005). Essa condição mostra a impossibilidade de se atribuir, no discurso literário, assim como nos outros discursos constituintes, um lugar ao enunciador, mas apenas negociar um lugar e um não-lugar.

\section{A paratopia de criação}

Para Maingueneau (1995), as categorias de autor, enunciação e sociedade são imprescindíveis para uma análise do discurso literário em uma concepção discursiva, pois a literatura se encontra em um não-espaço de criação, ou seja, é impossível, para um escritor, produzir a partir de um "solo institucional neutro e estável" (MAINGUENEAU, 1995, p. 28) e, por causa disso, o escritor "nutre seu trabalho com o caráter radicalmente problemático de seu próprio pertencimento ao campo literário e à sociedade" (1995, p. 27).

É importante salientar que, nesse aspecto, a perspectiva discursiva compreende como diferentes três instâncias relacionadas à produção do discurso literário. Para Maingueneau (1996), cabe identificar a problemática polifônica que toca a identidade do sujeito enunciador de um discurso de modo a se separar as instâncias do produtor físico do enunciado; do enunciador, origem da referência dos embreantes, e a do locutor, responsável pelo ato ilocutório do discurso.

Se em muitos discursos essas três instâncias são assumidas ao mesmo tempo por quem profere o enunciado, no discurso literário não é bem assim. Maingueneau (1996), assevera que é necessário, ao tratar do campo literário, realizar uma desambiguização entre as instâncias de autor e escritor: de um lado temos o autor, aquele 
que se responsabiliza pela enunciação; de outro, o escritor, o equivalente ao sujeito falante, a pessoa empírica e jurídica que habita o universo social

O simples fato de que bem frequentemente os escritores publicam sob um pseudônimo é revelador do corte que o discurso literário estabelece entre a instância produtora e a instância que assume a enunciação. Assinar por pseudônimo é construir ao lado do "eu" biográfico a identidade de um sujeito que só tem existência na e pela instituição literária. O recurso ao pseudônimo implica a possibilidade de isolar, no conjunto ilimitado das propriedades que definem o escritor, uma propriedade particular, a de escrever literatura, e de fazer dela o suporte de um nome próprio. (MAINGUENEAU, 1995, p. 87, grifo do autor)

Se, por um lado, é a pessoa do escritor que ocupa os espaços institucionais destinados ao evento da produção literária, das academias, do lançamento em noite de autógrafo; por outro, é o autor (écrivain) que ocupa um espaço desejado, paratópico, o espaço da criação, pois é este quem assume a enunciação. Desse modo, para analisar a paratopia do discurso literário, salientamos que, por autor de "O filho de Luísa", não tratamos do sujeito empírico de Joel Rufino dos Santos, embora, traços de sua biografia possam ser elencados dentro das condições de produção do discurso.

Maingueneau (2008) afirma que, na condição de enunciador de um discurso constituinte, o estatuto de autor não é evidente, pois "ele não pode se pôr nem no exterior nem no interior da sociedade" (p.45), de modo que há uma difícil negociação entre o lugar 
e o não-lugar da enunciação. Em outras palavras, o autor tem um pertencimento paradoxal, ele não pode legitimar sua enunciação em nenhuma instituição, uma vez que ele não fala de determinado lugar, mas é a sua própria criação que institui o seu lugar. "Nem suporte, nem quadro, a paratopia envolve o processo criador, que também a envolve: criar uma obra é, em um só movimento, produzir uma obra e construir através dela as condições que permitem produzi-la." (MAINGUENEAU, 2008, p. 46).

Em “O filho de Luísa”, o lugar da enunciação vai sendo criado por meio do discurso. $\mathrm{O}$ enunciador, ao dizer que "uma boa história pode começar de qualquer maneira", vai, pelo discurso, tentando criar o seu lugar de enunciação, em que se pode começar uma "história", em que se pode "começar na quitanda" e até mesmo deixar para depois algumas informações relevantes. O autor é paratópico, ele, ao enunciar, cria as possibilidades dessa mesma enunciação. Segundo os estudos de Candido (2011), o homem, desde a infância, possui a capacidade de fabular; mergulha, por meio do sonho, no mundo da ficção e da poesia, o que coloca a Literatura, em seu sentido mais amplo, como uma necessidade universal do ser humano. E esse caráter universalizante do discurso literário deve ser analisado com cuidado, pois

"uma obra literária corresponde a figura física que a produziu, mas que insistimos em conduzi-la para uma dimensão social apartada de sua produção. Faltam-nos os mecanismos adequados que nos permitam supor que aquela obra surgiu de certas conveniências sociais e culturais vividas pelo autor, o que inclui acesso a certos espaços de projeção de sua figura." (MOURA, 2006, p. 13) 
Vemos, então, que o discurso literário não pode pertencer completamente ao espaço social, uma vez que, pela sua intenção de universalidade, não pode ser alocado em nenhum lugar específico da sociedade, o que obriga, segundo Maingueneau (2018, p. 92), "os processos criadores a alimentar-se de lugares, grupos comportamentos que são tomados de um pertencimento impossível".

Assim, é a partir da perspectiva da atividade da criação literária, que está intimamente ligada a uma impossibilidade de pertencimento do autor, que fica sem um lugar definido, que verificamos a singularidade da enunciação do discurso literário. A produção de discursos inseridos em uma determinada obra literária "não pode ser totalmente desassociada de um posicionamento estilístico e ideológico, pois sugere identificação com os elementos marginalizados socialmente e com o espaço dado a esses" (MOURA, 2006, p.12). Assim, a paratopia consolida-se na e pela da criação literária do autor, ela é a condição e o produto do processo de criação artística.

A paratopia do escritor, na qualidade de condição da enunciação, também é seu produto; é por meio da paratopia que a obra pode vir à existência, mas é também essa paratopia que a obra deve construir em seu próprio desenvolvimento. Na qualidade de enunciação profundamente ameaçada, a literatura não pode dissociar seus conteúdos da legitimação do gesto que os propõe; a obra só pode configurar um mundo se este for dilacerado pela remissão ao espaço que torna possível sua própria enunciação. (MAINGUENEAU, 2018, p. 119) 
A autolegitimação é condição da enunciação do discurso literário, fruto de uma inalcançável inscrição social do autor, que produz uma obra literária. Esta última, de acordo com Maingueneau (2001) é criada através das tensões do campo propriamente literário. Ela se constitui em um embate com os ritos, as normas, as relações de força das instituições literárias, e só pode dizer algo do mundo, porque se inscreve no funcionamento do lugar que a tornou possível, "colocando em jogo, em sua enunciação, os problemas colocados pela inscrição social de sua própria enunciação" (MAINGUENEAU, 2001, p. 30).

Em “O filho de Luísa”, podemos verificar a emergência de um autor que se desvencilha do lugar do historiador, que direciona seu conhecimento para um novo lugar, mais leve, mais fluido, da literatura, e que exalta a identidade um povo. É possível perceber, por meio do código linguageiro, as cenas da enunciação e até mesmo os paratextos a criação de um lugar de enunciação do negro e das histórias que fazem parte do imaginário dele, um lugar insustentável.

Ao fazer referência aos fatores sociais, o escritor tende a se reconhecer em figuras que ocupam um espaço de marginalidade, como "boêmios, judeus, mulheres, palhaços, aventureiros, índios americanos" (MAINGUENEAU, 2009, p. 98-99), dentre outras categorias que estabelecem ligações com os setores que oferecem uma potencialidade condicionalmente paratópica, dos quais a atividade de criação literária se alimentará de forma parasitária.

Entretanto, cabe salientar que a literatura é uma atividade artística também, assim, há uma construção discursiva acerca da figura do artista, que, no contexto social da contemporaneidade, goza de um privilégio de escrever, mesmo que também seja visto como o ocupante de uma função social nula. Segundo Assunção 
e Moura (2017, p. 173), é esse paradoxo que leva a sociedade a condenar o trabalho do escritor como "um trabalho do qual não se exige esforços ou como uma ocupação para fugir do ócio", colocando o escritor em um espaço fronteiriço com relação à sociedade, pois representa uma figura ambivalente, boa e má, necessária e perniciosa. Nisso, pois, está a paratopia do escritor: ser de uma só vez o impuro e a fonte do inefável, o pária e o gênio. "Estando na fronteira da sociedade organizada, o artista é aquele em que se mesclam perigosamente as forças maléficas e as forças benéficas" (MAINGUENEAU, 2018, p. 100).

Ainda, de acordo com Maingueneau (2005), a paratopia, que também é um fenômeno relacionado ao fator espacial, pode ser classificada em: paratopia de identidade (familiar, sexual e social), que se dá pela imagem marginalizada concernente ao lugar em que se encontra; paratopia espacial, que se dá através do exílio ou do nomadismo; paratopia temporal, que possui característica anacrônica com relação ao contexto em que se encontra; e paratopia linguística, que representa um distanciamento da língua materna e/ ou uma hibridização de línguas.

Há, dentro do discurso literário, levando em consideração as condições de enunciação, o que Maingueneau chama de embreagem paratópica, que, semelhante à embreagem linguística, é formada de

elementos que participam simultaneamente do mundo representado pela obra e da situação paratópica através da qual se institui o autor que constrói esse mundo" (2018, p. 121). 
A embreagem paratópica pode se desenvolver de diversas formas e requer, simultaneamente, identificação e distanciamento, não estando relacionada somente a um elemento, de forma isolada, mas a uma teia de relações com a qual esse elemento está envolvido.

Focaremos, então, a análise do nosso corpus, à luz da categoria da paratopia no intuito de nos entranharmos nesse espaço de conflito em que se inserem as produções discursivas literárias no âmbito do processo da criação literária. Essa dualidade espacial em que se encontra esse discurso de não-pertencimento a um dado espaço social e, ao mesmo tempo, pertencente a todo e qualquer lugar gera uma problemática de insustentabilidade, que resulta na própria questão existencial desse discurso, bem como a do autor:

Enquanto discurso constituinte, a instituição literária não pode de fato pertencer plenamente ao espaço social, mantendo-se na fronteira entre a inscrição em seus funcionamentos tópicos e o abandono a forças que exercem por natureza toda a economia humana. (MAINGUENEAU, 2018, p. 92)

O discurso literário está na fronteira entre a inscrição em seus funcionamentos tópicos (da sociedade) e o afastamento desses mesmos funcionamentos e do que é esperado. Vemos, então, que é exatamente por ser um discurso constituinte que o discurso literário engendra a existência de uma impossibilidade de pertencimento ao espaço social. Por isso, a literatura, como todo discurso constituinte, está no lugar da negociação de pertencimento, na paratopia. 
Com base no exposto, trataremos da produção discursiva do escritor Joel Rufino dos Santos, em "O filho de Luísa” (SANTOS, 2005), tendo como enfoque a identidade enunciativa que emerge nas relações paradoxais que o autor estabelece com a sua obra, identificando e observando os aspectos e fatores que contribuem para a caracterização dos elementos paratópicos inerentes ao processo de criação.

\section{Análise}

O discurso literário traz consigo marcas no código linguageiro que evidenciam a paratopia de criação, ora, esse é um tipo de discurso, como defendido acima, que não tem um campo definido, logo, é por meio da enunciação que são criadas as condições para o dizer.

Em "O filho de Luísa”, pela paratopia de escritor, vemos emergir uma identidade enunciativa de um contador de histórias, mas esse auctor se constitui em um embate entre os campos da Literatura e da História. No discurso, podemos perceber que esse autor se mostra em momentos específicos explicitando a paratopia.

\section{Recorte 1}

Uma boa história pode começar de qualquer maneira. Esta começa com uma quitandeira da Bahia.

O sobrenome deixo para dizer depois.

Não sei. Quando começou esta história, ela já era livre 
Não sei. Queria apenas contar urna história e já estou enredado em discussão.

Batizaram-no Luís, mas não vou dizer o sobrenome. (SANTOS, 2005)

Nos trechos do Recorte 1, é possível verificar traços da criação do discurso literário que se opõem às práticas dos relatos da História. Aqui, o enunciador reflete sobre a própria prática discursiva - o que é "uma boa história", como ela começa -, expõe sua própria intenção - quer é "contar uma história e não se enredar em discussões - e realiza protelações conscientes para criar uma espécie de suspense.

Nota-se, então, que o autor deixa transparecer no discurso traços do processo criativo, criando uma identidade enunciativa. Esta não se confunde com a identidade da pessoa empírica do professor Joel Rufino dos Santos, mesmo que este último, porque historiador, tenha uma autoridade para narrar a biografia de Luís Gama. O processo criativo do discurso literário rompe com as convenções da História, de modo que o enunciador de "O filho de Luísa" participa do campo discursivo literário.

O ethos do contador de história emerge, assim, podendo criar uma espécie de suspense ao esconder o sobrenome das figuras históricas apresentadas no discurso. Ao tratar de Luísa e Luís, sem sobrenome, o enunciador cria um jogo de esconde-esconde responsável por gerar, na revelação, um clímax, uma catarse. Apenas ao terminar de ouvir a história os demais participantes da interação deverão resgatar na memória discursiva quem foram Luísa Mahin e Luís Gama, renovando os efeitos de sentido construídos até então. 
O discurso literário de Joel Rufino dos Santos é transpassado pelo discurso de valorização da negritude e do negro, pois coloca em evidência figuras icônicas da luta contra a escravidão e apresenta elementos de oposição entre o negro e o branco.

\section{Recorte 2}

Luísa era pequena, bem negra e tinha lábios roxos - diferente de quase todo mundo, que tem lábios cor-de-rosa.

Para Luísa, porém, ter outra religião não era problema.

Luísa tinha outra estranheza. Quer dizer, que se considerava estranheza.

Namorava negros e brancos. Não olhando a cor, se apaixonava dia sim, dia não.

Luísa fazia parte de uma sociedade secreta de negros malês. Eram negros de religiões não cristãs, que preparavam uma revolta pela liberdade de todos os escravos da Bahia.

Luíza era mulçumana e simpatizava com o candomblé, de forma que era a pessoa ideal para o movimento.

Luísa, é claro, ficou muitíssimo agradecida.

Luísa continuava agradecida.

Era inteligente e determinado como a mãe - que, agora posso dizer, se chamava Luísa Mahin. (SANTOS, 2005) 
O discurso sobre a mulher negra presente no Recorte 2 fundamentalmente destaca seus valores. Luísa é descrita como mulher negra, tolerante, simpática - para quem religião não é um problema -, consciente dos problemas da escravidão - mesmo não sendo escrava lutava pela liberdade -, forte, trabalhadora, inteligente, determinada etc.

Esse discurso de valorização da mulher negra em uma posição de destaque é um ato de decolonização. Ele apresenta um posicionamento contra os valores coloniais tornando o escritor um autor validado e legitimado para reinventar a si mesmo por meio da história. Kilomba (2019, p. 28) diz que sua escrita "representa esse desejo duplo: o de se opor àquele lugar de 'Outridade' e o de inventar a nós mesmos de modo novo [...] e pode ser entendida como uma forma de 'tornar-me sujeito"'.

Vê-se que a construção de uma identidade de negritude ultrapassa o conteúdo da narrativa, mas se vale dele para que a construção identitária se dê na enunciação. Segundo Hall (1990), o negro, correntemente, fala sobre si mesmo e sobre sua realidade, a partir de sua perspectiva que tem sido calada por muito tempo. $\mathrm{O}$ processo criativo paratópico, nesse caso, é, sobretudo, "uma questão tanto relativa ao passado quanto ao presente, [...] um diálogo constante entre ambos, já que o racismo cotidiano incorpora uma cronologia que é atemporal” (Kilomba, 2019, p. 29).

Desse modo, o discurso literário de Joel Rufino dos Santos reconstrói a história do povo negro de uma via dupla, ao exaltar a figura do negro por meio do discurso e ao construir uma posição de sujeito que o próprio autor, paradigmaticamente, ocupa.

Entretanto, essa figura de negritude que aparece no discurso é adjetivada com "estranha", "diferente de quase todo mundo", ou 
seja, ela também se constrói em oposição a outra figura, a do branco colonizador.

\section{Recorte 3}

Luísa também não era cristã, Era um problema? Para as autoridades era. Tinham receio de negros que não fossem cristãos.

Oliveira sapecou-lhe um beliscão no pescoço. Luísa respondeu com uma ombrada que jogou Oliveira no chão. Era a paquera da época.

Em fevereiro de 1835, estourou a revolução dos malês. Luísa foi presa e comeu o pão que o diabo amassou. Castigada com duzentas chibatadas, teve hora que ela desejou ter morrido. Pensou que ia apodrecer na cadeia. Mas, um belo dia, quem veio soltá-la? Oliveira. Ele era branco e foi ao juiz com uma conversa comprida: ia se responsabilizar pela quitandeira e coisa e tal.

ela contou uma coisa para ele: estava grávida e tinha sido uma sorte não perder a criança. Oliveira também contou uma coisa: era jogador profissional de cartas

Luísa continuava agradecida. Jurou que não ia mais se meter em revolução. Em troca, Oliveira jurou que ia procurar trabalho honesto e largar os ases e os curingas. 
Nenhum dos dois cumpriu o prometido. Um dia estourou nova revolução de malês. Luísa combateu e voltou a ser presa. Oliveira arrumou uma dívida grande no jogo.

"Esse é um filho, que te falei". Piscaram o olho. O homem, zaque! Botou algemas no garoto.

- Pai, manda ele me soltar! - pediu Luisinho.

Oliveira foi escapulindo de mansinho:

- Perdão, meu filho. Mas foi tua mãe que mandou te vender. (SANTOS, 2005)

O discurso decolonial constrói a figura do branco colonizador por meio da imagem de Oliveira e do Estado. Vê-se que as autoridades são compostas por pessoas medrosas - têm medo de negros não cristãos - e perversas - açoitam Luísa com 200 chibatadas mesmo estando grávida a ponto de ela desejar a morte. Já Oliveira é descrito como um português, branco, que tem lábia de convencimento para influenciar a justiça, um jogador que não desempenha trabalho honesto, um enganador que vende o próprio filho para pagar dívidas de jogo.

Oliveira representa o homem de uma sociedade cuja identidade era bem definida e localizada no mundo social e cultural. Enquanto homem branco colonizador, ele é a figura que, por muito tempo, foi/é o padrão exemplar nos discursos dominantes. No entanto, segundo Hall (2015), como todas as identidades estão sendo fragmentadas, várias outras identidades socioculturais, seja de classe, de sexualidade, de etnia, de raça, de nacionalidade etc., são possíveis verificar. A velha ideia de estabilidade está em declínio e as sólidas estruturas sociais nas quais os indivíduos se encaixavam 
deram lugar a um mundo líquido (a pós-modernidade), provocando uma crise de identidade.

Apenas nessas condições um discurso como o de Joel Rufino dos Santos pode surgir. Um discurso que, dentro do campo literário, objetivando reconstruir realidades no universo infantil, pode apresentar um posicionamento antiescravagista e criar uma forte oposição entre as figuras da mulher negra e do homem branco. Ainda no mesmo Recorte 3, pode-se verificar as dicotomias criadas para opor as duas figuras:

\begin{tabular}{|l|l|}
\hline Mulher negra & Homem branco \\
\hline Ombrada & Beliscão \\
\hline Lutou a Revolução & Conversa comprida \\
\hline Quitandeira (trabalho honesto) & Jogador profissional de cartas \\
\hline Combateu nova Revolução & Arrumou dívida de jogo \\
\hline $\begin{array}{c}\text { Leva chibatadas grávida e não } \\
\text { perde o filho }\end{array}$ & Vende o filho como escravo \\
\hline
\end{tabular}

É possível verificar que, ao criar várias oposições, o discurso decolonial que atravessa o discurso literário recria a história da negritude e do povo negro no Brasil, evidenciando suas lutas, sua força, exaltando sua resistência e expondo situações que ficam à margem da História oficial.

Luís Gama é uma figura conhecida no Brasil, homenageado com nome em escolas, faculdades, ruas, instituições de direitos humanos etc., devido a sua grande contribuição para a Abolição da Escravidão. Por causa disso, no processo de criação, o autor se refere a ele utilizando paratopias que conservam sua identidade até quase o final do conto. 
Recorte 4

O filho de Luísa

Batizaram-no Luís, mas não vou dizer o sobrenome.

Era negro fosco como Luísa e tinha a testa alta e o nariz fino como Oliveira.

Botou algemas no garoto.

Luisinho, acorrentado no porão, chorou até o Rio de Janeiro.

Luís foi vendido pra São Paulo. Subiu a pé, acorrentado pelo pescoço, a Serra do Mar. Era inteligente e determinado como a mãe.

O sofrimento da escravidão não o destruiu. Uma das suas tarefas era estudar com os filhos do senhor.

Aproveitou para aprender o que eles tinham preguiça de aprender.

Se tornou rábula, que quer dizer advogado sem diploma.

Começou provando no tribunal que tinha direito à liberdade, pois era filho de uma mulher livre. Em seguida, iniciou - junto com outros estudantes e jornalistas - a Campanha Abolicionista.

Conseguiu, ele sozinho, libertar mais de mil escravos, provando na Justiça que eles tinham direito à liberda- 
de porque tinham sido escravizados depois da proibição do tráfico. Seu nome e sobrenome: Luiz Gama. (SANTOS, 2005)

No Recorte 4, verificamos que, no processo criativo, a paratopia de identidade é o cerne da criação do discurso literário em análise. Ela se dá desde o título, em que se trata das relações familiares no lugar de utilizar o nome do indivíduo em uma tentativa de preservar a identidade. Esse recurso é reiterado ao longo de todo o texto com: "filho", garoto, "o", "ele", "estudante", "jornalista", "Luís", "Luisinho", "não vou dizer o sobrenome". Desse modo, ao não nomear Luís Gama, termo que poderia ser o título do conto, o autor transporta o que poderia ser uma biografia para o campo da ficção literária.

Além disso, na figura de Gama, é possível encontrar o que Maingueneau (2018) chama de paratopia familiar: Luís é escravizado, filho de pai livres; é negro, filho de pai português que o vendeu. É exatamente esse pertencimento paradoxal - pertence e não pertence à família - que caracteriza a paratopia, isso porque, como afirma Maingueneau (2018, p. 109),

a paratopia envolve o processo criador, que também a envolve: fazer uma obra é, num só movimento, produzi-la e construir por esse mesmo ato as condições que permitem produzir essa obra. Logo, não há "situação" paratópica exterior a um processo de criação: dada e elaborada, estruturante e estruturada, a paratopia é simultaneamente aquilo de que se precisa ficar livre por meio da criação e aquilo que a criação aprofunda; é a um só tempo aquilo que cria a possibilidade de acesso a 
um lugar e aquilo que proíbe todo pertencimento. Intensamente presente e intensamente ausente deste mundo, vítima e agente de sua própria paratopia, o escritor não tem outra saída que a fuga para a frente, o movimento de elaboração da obra.

Como se pode verificar, é exatamente o movimento criador paratópico que oferece as condições que permitem a produção do discurso literário de Joel Rufino dos Santos. Ao não nomear Luís Gama, o filho de Luísa é apenas um menino negro, e, por ser um menino negro que superou e combateu a escravidão é que ele pode ser Luís Gama.

A paratopia de identidade, como se vê, é o motor de criação desse discurso. Não apenas no âmbito familiar, ela também incide no pertencimento instável permeia o discurso, por exemplo pela classe de advogados, Luís Gama é e não é advogado ao mesmo tempo, ele é rábula; e até mesmo na questão da escravidão, ele é e não é um escravizado.

Os elementos apresentados servem como embreagens paratópicas para a construção da identidade da negritude que, em consonância com o que foi apresentado sobre o Recorte 2, exaltam os valores de um povo na figura singular e reforçam seu caráter de resistência, resiliência, inteligência e luta.

\section{À guisa de conclusão: uma construção identitária}

Neste capítulo, com uma breve análise da produção discursiva do escritor Joel Rufino dos Santos, em "O filho de Luísa" (SANTOS, 2005), foi possível verificar que a identidade enunciativa que 
emerge nas relações paradoxais que o autor estabelece com a sua obra, identificando e observando os aspectos e fatores que contribuem para a caracterização dos elementos paratópicos inerentes ao processo de criação.

A identidade do povo negro no Brasil, porque negada por tanto tempo, uma vez que privado de sua voz (Kilomba, 2019), passa por um processo de construção que se vale dos recursos enunciativos dos discursos, principalmente do discurso constituinte literário, pois, por um lado, a literatura é exaltada como um veículo de descompressão dos pensamentos, de abundância de mundos e possibilidades, de pluralidade de seres, de aceitação do diferente; e por outro, é também espaço de conservação da memória de uma sociedade, da tradição, de recuperação de um passado imemorial etc.

Verificou-se que são construídas imagens do negro, da mulher negra e do homem branco colonizador, no discurso, de quem as imagens são construídas em oposição de modo que a história da escravidão e do negro é contada por uma nova ótica. O negro deixa o lugar de objeto para assumir o papel de sujeito. Sendo assim, a relação paratópica do autor com sua obra pode ser considerada como um fator intrínseco ao seu processo de criação artístico-literária, compreendido como o que nutre a atividade escrita.

Emerge, no discurso literário, um sujeito negro (KILOMBA, 2019), uma identidade da negritude que assume o papel de contar a própria história, de resistir à história única e de fixar novas bases paradigmáticas para o futuro. 


\section{Referências}

ADICHIE, Chimamanda Ngozi. O perigo de uma história única. São Paulo, Cia. Das Letras, 2019.

FERREIRA, Ligia Fonseca. "Luiz Gama por Luiz Gama: carta a Lúcio de Mendonça”, in: Teresa. Revista de Literatura Brasileira da USP [n. 8/9], São Paulo, p. 300-321.

HALL, Stuart. "Cultural identity and diaspora." Identity, community, culture, difference. London: Lawrence \& Wishart Limited, 1990. p. 222-237.

HALL, Stuart. Identidade cultural na pós-modernidade. 12 ed. Rio de Janeiro: Lamparina, 2015.

hooks, bell. Talking back: thinking feminist, talking back. Boston: South End Press, 1989.

hooks, bell. Yearning. Race, gender, and cultural politics. Boston: South End Press, 1990.

KILOMBA, Grada. Memórias da plantação: episódios de racismo cotidiano. Rio de Janeiro: Cobogó, 2019.

MAINGUENEAU, Dominique. O discurso literário contra a literatura in: MELLO, R. Análise do discurso \& Literatura, Belo Horizonte: NAD/FALE/UFMG, 2005.

MAINGUENEAU, Dominique. Gênese dos Discursos, trad. Sírio Possenti, São Paulo: Parábola, 2008.

MAINGUENEAU, Dominique. O Discurso Literário. Trad. Adail Sobral. São Paulo: Contexto, 2018.

PROENÇA FILHO, Domício. A trajetória do negro na literatura brasileira. Estud. av. vol. 18. n. 50. São Paulo. Jan./Abr. 2004.

SANTOS, Joel Rufino dos. O filho de Luísa. In: Gosto de África: histórias de lá e daqui. 4 ed. São Paulo: Global, 2005. p. 9-14. 
